January 2004

\title{
Munazza's story: Shedding light on a science teacher's conceptions of the nature of science through a life history study
}

Nelofer Halai

Aga Khan University, Institute for Educational Development, Karachi

Derek Hodson

Ontario Institute for Studies in Education of the University of Toronto

Follow this and additional works at: http://ecommons.aku.edu/pakistan_ied_pdck

Part of the Educational Administration and Supervision Commons, Junior High, Intermediate, Middle School Education and Teaching Commons, and the Science and Mathematics Education Commons

\section{Recommended Citation}

Halai, N., Hodson, D. (2004). Munazza's story: Shedding light on a science teacher's conceptions of the nature of science through a life history study. Canadian Journal of Science, Mathematics and Technology Education, 4(2), 193-208.

Available at: http://ecommons.aku.edu/pakistan_ied_pdck/25 
This article was downloaded by: [INASP - Pakistan (PERI)]

On: 14 March 2012, At: 09:28

Publisher: Routledge

Informa Ltd Registered in England and Wales Registered Number: 1072954 Registered office: Mortimer House, 37-41 Mortimer Street, London W1T 3J H, UK

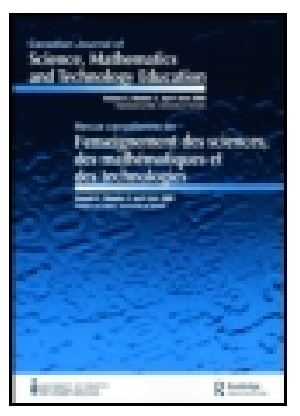

\title{
Canadian J ournal of Science, Mathematics and Technology Education
}

Publication details, including instructions for authors and subscription information: http:// www.tandfonline.com/loi/ ucjs20

\section{Munazza's story: Shedding light on a science teacher's conceptions of the nature of science through a life history study}

\author{
Nelofer Halai ${ }^{a} \&$ Derek Hodson ${ }^{b}$ \\ a Aga Khan University, Karachi \\ ${ }^{\mathrm{b}}$ Ontario Institute for Studies in Education, University of Toronto, \\ Available online: 26 J an 2010
}

To cite this article: Nelofer Halai \& Derek Hodson (2004): Munazza's story: Shedding light on a science teacher's conceptions of the nature of science through a life history study, Canadian J ournal of Science, Mathematics and Technology Education, $4: 2,193-208$

To link to this article: http:// dx.doi.org/ 10.1080/14926150409556605

\section{PLEASE SCROLL DOWN FOR ARTICLE}

Full terms and conditions of use: http://www.tandfonline.com/page/terms-and-conditions

This article may be used for research, teaching, and private study purposes. Any substantial or systematic reproduction, redistribution, reselling, loan, sub-licensing, systematic supply, or distribution in any form to anyone is expressly forbidden.

The publisher does not give any warranty express or implied or make any representation that the contents will be complete or accurate or up to date. The accuracy of any instructions, formulae, and drug doses should be independently verified with primary sources. The publisher shall not be liable for any loss, actions, claims, proceedings, demand, or costs or damages whatsoever or howsoever caused arising directly or indirectly in connection with or arising out of the use of this material. 


\title{
Munazza's Story: Shedding Light on a Science Teacher's Conceptions of the Nature of Science through a Life History Study
}

\author{
Nelofer Halai \\ Aga Khan University, Karachi \\ Derek Hodson \\ Ontario Institute for Studies in Education of the \\ University of Toronto
}

\begin{abstract}
Life history research creates a broader understanding of teaching by providing illustration of the relationships among various aspects of teachers' lives and their teaching practice, both inside and beyond the classroom. This article focuses on the life history of Munazza, a young science teacher at the Karachi Model Secondary School (KMSS), a private, co-educational, English-medium school for children from middle-income families. Its purpose is to gain insight into a female science teacher's understanding of teaching science in a school in Pakistan, ascertain what aspects of this science teacher's conceptions of the nature of science are explicit in her practice, and determine how the teacher's life history has affected those views.
\end{abstract}

Sommaire executif: Pour bien comprendre les processus décisionnels chez les enseignants et pour leur donner des conseils qui soient utiles à leur développement professionnel, il est nécessaire de bien comprendre leurs expériences aussi bien à l'intérieur qu'à l'extérieur de la salle de classe. C'est cette prémisse qui est à la base de la présente étude. Nous présentons l'histoire de Munazza (pseudonyme), jeune enseignante de sciences qui travaille à la Karachi Model Secondary School (KMSS), une école privée mixte de langue anglaise à l'intention des enfants provenant de familles de niveau économique moyen, à Karachi, au Pakistan. La recherche visait à mieux comprendre le point de vue d'une femme qui enseigne les sciences dans une école du Pakistan sur la matière qu'elle enseigne, à cerner les aspects de ses idées sur la nature des sciences qui sont explicites dans sa pratique de l'enseignement et à déterminer de quelle façon l'histoire personnelle de cette enseignante a pu influencer ses idées. Cet article est centré sur ces trois objectifs, mais se penche tout particulièrement sur l'analyse des conceptions de Munazza sur la nature des sciences.

Cette méthode de recherche basée sur l'histoire personnelle consent au chercheur d'adopter une plus vaste définition de l'enseignement en illustrant les liens qui existent entre différents aspects de la vie des enseignants et leur pratique de l'enseignement, dans la salle de classe et ailleurs. Les histoires personnelles nous rappellent également qu'on ne peut éviter de tenir compte des façons dont les expériences précoces des enfants, à l'intérieur et à l'extérieur de la classe, influencent les choix professionnels et, dans le cas des enseignants, influencent les décisions qu'ils prennent dans le cadre des curriculums.

Les données ont été recueillies grâce à une série de treize entrevues visant à connaître l'histoire personnelle de l'enseignantè, à de nombreuses conversations non structurées et à plus de trente séances d'observation des leçons de sciences dispensées par Munazza à des élèves de septième et de huitième années, sur une période de dix-sept mois. D'autres enseignants de sciences de la KMSS ont également été interviewés afin de fournir une meilleure description du contexte éducatif dans lequel travaillait Munazza. Le travail avec une seule enseignante servait mieux notre objectif de " généralisation naturaliste » (Stake et Trumbull, 1982) que ne l'aurait fait l'étude d'un groupe d'enseignants. 
Il y a au cœur de cette méthode un type particulier de procédé d'entrevue qui est nécessaire pour reconstruire ensemble l'histoire personnelle des participants à la recherche. Le but des entrevues n'était pas de vérifier des hypothèses, mais bien d'artiver à une meilleure compréhension des expériences vécues par l'enseignante et de l'importance qu'elle attribuait à ces expériences. Les entrevues se sont déroulées en Urdu, langue nationale du Pakistan, parce que l'expérience montre que les enseignants sỏnt beaucoup plus à l'aise lorsqu'ils s'expriment dans leur propre langue. De brefs épisodes de la vie de Munazza sont mis en évidence sous forme de récit personnel. Certains procédés rhétoriques ont été utilisés pour transformer les données en récit. Par exemple, le pronom " je » est utilisé pour représenter la voix de Munazza. En laissant l'enseignante raconter son histoire personnelle dans ses propres mots, nous avons tenté d'éliminer les interférences d'un intermédiaire et de la rapprocher des lecteurs. Pour éclairer sa pratique de l'enseignement, nous avons construit un récit composite, sorte de mosaïque ou collage de ses souvenirs personnels, de ses opinions et de ses actions, interprétés à la lumière des entrevues et des observations de classe.

De longues conversations avec Munazza ainsi que l'observation de nombreuses leçons en classe sur une période de dix-sept mois indiquent que sa conception de la nature des sciences comprend cinq éléments significatifs, tous profondément ancrés dans son histoire personnelle :

- L'observation est indépendante de la théorie

- Les sciences sont un ensemble de connaissances reçues

- Les sciences sont une forme de savoir neutre, stable et supérieur

- L'enseignement des sciences est principalement une enculturation au langage des sciences

- Les sciences sont un sujet masculin

Cette recherche est particulièrement importante pour ce qu'elle révèle sur les pratiques de développement professionnel au Pakistan. Elle montre combien les expériences très personnelles comme étudiante sont liées aux pratiques d'enseignement de Munazza et met en évidence comment les événements qui sillonnent la vie d'une enseignante sont susceptibles d'influencer son enseignement. Elle montre également qu'en aidant les enseignants à découvrir et à analyser ces incidents importants, on peut les aider à comprendre, à critiquer et à reconceptualiser leur enseignement. Il est aussi possible d'améliorer l'enseignement des sciences grâce à la mise sur pied d'activités visant à aider les enseignants à reconstruire leurs propres concepts sur la nature des sciences et à se servir de ces mêmes activités pour enseigner ces concepts aux étudiants. Au Pakistan, le plus grand défi n'est pas de développer de nouveaux curriculums et de nouvelles idées, mais bien de soutenir les enseignants qui doivent les appliquer et les redéfinir pour mieux servir leurs besoins particuliers et les besoins de leurs étudiants. Cette étude montre très clairement que les enseignants se servent de leurs connaissances pratiques personnelles pour prendre des décisions sur ce qu'ils enseignent dans la classe et sur leur façon d'enseigner, et que la base de ce type de connaissances est ancrée dans leur histoire personnelle. Il s'ensuit que les efforts pour développer des curriculums pertinents, et le développement professionnel des enseignants qui y est-associé, doit viser à faire de ces activités une partie importante de l'expérience de tous les enseignants.

\section{Introduction}

Students' daily experiences in science classrooms are a consequence of the decisions their teachers make about what to teach, when to teach, how to teach, how to monitor progress, and so on. Some of these decisions are long-term strategic decisions about what to do this year or next year, this month or next month. Some are decisions taken within a particular lesson, in response to evaluative questions. Is the lesson proceeding satisfactorily? If not, what can be done about it? In other words, curriculum decision making occurs along a continuum, ranging from moment-tomoment decisions in response to what a particular student says or does to grand decisions about the overall purpose, thrust, and structure of the science curriculum and its relationship to other subjects.

Of particular interest to teacher educators is the nature of the decision making. How does a teacher make decisions? What is the basis for making this decision rather than some other? Clearly, each of us makes decisions in relation to what we know, what we have experienced, and what sense 
we have made of those experiences. How could it be otherwise? What is also true is that if we knew different things and if our experiences had been different, we might have made different decisions. Hence the old adage: 'When we know better, we do better.' The knowledge on which teachers draw, both consciously and unconsciously, includes knowledge of science (biology, chemistry, physics, geology, etc.), knowledge about science (history, philosophy, and sociology of science, for example), and knowledge of education-the education system, learning, pedagogy, children in general (including the ways in which motivational factors, affective issues, and social dimensions affect learning), and school in general (the language, code of behaviour, expectations, and cultural norms of school). Most importantly, it includes knowledge of this school, this class, this neighbourhood, and these particular children/students, and it includes what Shulman $(1986,1987)$ calls 'pedagogical content knowledge'-knowing what is likely to be easy or difficult for students to leam and how to organize, sequence, and present the content in ways that meet the diverse needs, interests, abilities, and aspirations of students and simultaneously meet the demands of the curriculum and the examination system. Skilful teachers utilize this body of pedagogical content knowledge $(\mathrm{PCK})$ to design and implement situationally appropriate learning experiences for their students.

Connelly and Clandinin $(1985,1988)$ refer to this complex of knowledge on which teachers draw in order to make their curriculum decisions as 'personal practical knowledge.' From our perspective, the significant aspect of personal practical knowledge is that it is not a body of pre-existing, validated knowledge to be acquired by teachers and subsequently applied to practice. Rather, it is transient, subject to change, and situated in personal experience both inside and outside the classroom. In Clandinin's (1986) words, it is 'experiential, value-laden and oriented to practice' (p. 19), though it may not always be the outcome of conscious reflection.

What is meant by 'personal' ... is that the knowledge so defined participates in, and is imbued with, all that goes to make up a person. It is knowledge which has arisen from circumstances, actions and undergoings which themselves had affective content for the person in question ... knowledge which can be discovered in both the actions of the person and, under some circumstances, by discourse or conversation. By 'knowledge' ... is meant that body of convictions, conscious or unconscious, which have arisen from experience, intimate, social, and traditional, and which are expressed in a person's actions ... 'Personal practical knowledge' is knowledge which is imbued with all the experiences that make up a person's being. Its meaning is derived from, and understood in terms of, a person's experiential history, both professional and personal. (Clandinin, 1985, p. 362)

It follows that understanding teachers' decision making, and proffering useful advice for their continuing professional development, means understanding the lives of teachers both inside and outside the classroom. This is the justification for this particular research study. It is the story of Munazza, ${ }^{\prime}$ a young science teacher who works in the aftemoon shift ${ }^{2}$ of the Karachi Model Secondary School (KMSS), a private, co-educational, English-medium school for children from middle-income families in Karachi, Pakistan. Munazza has a BSc degree from a local college, where she studied chemistry and microbiology; she has been teaching science for nine years, four of those in KMSS. The school is part of a group of eleven schools run by a private trust interested in imparting quality education to the masses. The purpose of the study was to gain insight into a female science teacher's understanding of teaching science in a school in Pakistan, ascertain what aspects of the science teacher's conceptions of the nature of science are explicit in her practice, and determine how the teacher's life history has impacted those views. This article focuses on all three research goals but lays special emphasis on understanding Munazza's conceptions of the nature of science.

Defining the nature of science is no easy task. Even a cursory examination of the extensive literature in the history, philosophy, and sociology of science reveals little in the way of consensus about the nature of science and scientific inquiry. However, although there is no single, universally accepted view of science, there is a measure of agreement on a number of points relevant to the school science curriculum (Hodson, 1991; McComas, Clough, \& Almazroa, 2000). For the purpose 
of this study, the definition of the nature of science in the National Science Teachers Association ([NSTA], 2000) position paper proved adequate. An abridged version is quoted below. ${ }^{3}$

The following premises are important to understanding the nature of science:

- Scientific knowledge is simultaneously reliable and tentative.

- Although no single universal step-by-step scientific method captures the complexity of doing science, a number of shared values and perspectives characterize a scientific approach to understanding nature.

- Creativity is a vital ingredient in the production of scientific knowledge.

- A primary goal of science is the formation of theories and laws, which are terms with very specific meanings.

- Contributions to science can be made and have been made by people the world over.

- The scientific questions asked, the observations made, and the conclusions in science are to some extent influenced by the existing state of scientific knowledge, the social and cultural context of the researcher and the observer's experiences and expectations.

- The history of science reveals both evolutionary and revolutionary changes. With new evidence and interpretation, old ideas are replaced or supplemented by newer ones.

Although a number of questionnaire tools are available to identify and characterize teachers' conceptions of the nature of science (see review of the literature by Lederman, Wade, \& Bell, 1998), we chose not to use them. Our preference was to use more open-ended instruments and multiple sources of data, including interviews and classroom observations (Abd-El-Khalick, Bell, \& Lederman, 1998; Halai, 2002a; Nott \& Wellington, 1998). In particular, we used a narrative mode of research, using what is often called the life history method (Cole \& Knowles, 1993; Denzin, 1989; Goodson, 1992). The definition of life history adopted here is that proposed by Smith, Kleine, Prunty, and Dwyer (1986): stories or narratives recalling events in an individual's life, obtained with the help of lengthy interviews. It includes the stories of significant others, in order to embed the narrative in a broader context. By illustrating the relationships between various aspects of teachers' lives and their teaching practice, both inside and beyond the classroom, this method allows and encourages the researcher to adopt a broader understanding of teaching. Life histories also remind us not take for granted the ways in which childhood experiences, both inside and outside the classroom, influence career choice and, for teachers, their curriculum decision making.

Because teachers often have 'difficulty in articulating what they know and how they know it' (Shulman, 1987, p. 6), a clear understanding of the world of a science teacher cannot be gained by means of a single interview. Instead, one of us (Nelofer Halai) tried to 'get into the shoes' of this particular science teacher, by talking to her at length, observing her teaching over an extended period of time, and observing her interactions in the environment of the school. Data was gathered via a series of thirteen life-history interviews, ${ }^{4}$ numerous informal conversations, and more than 30 observations of Munazza's science lessons for Grades 7 and 8, over a period of 17 months. Other science teachers and administrative staff at KMSS were also interviewed to provide a deeper understanding of the educational context in which Munazza works. Working with a single teacher was better suited to our goal of 'naturalistic generalization' (Stake \& Trumbull, 1982) than studying a group of teachers. Nelofer chose to work with a female teacher because she felt that her own experience of school, as both a female student and a female teacher of science, provided some grounds for a shared understanding. Furthermore, because Pakistan is a highly patriarchal society, we were concerned that the power imbalance between the sexes might affect the research data. We believed that the close interaction and rapport with the teacher demanded by the research design could be achieved more easily with a female teacher. While there are cases of female researchers working with male teachers in Pakistan, the projects have been either quantitative or shorter qualitative projects involving a number of participant teachers (Halai, 1999). For an in-depth study of the life of a teacher, we felt that cultural sensitivity required that the teacher be female. 
The heart of the life history method is the special kind of interview process that is needed to co-construct the life of the research participant(s). The purpose of the interview is not to test hypotheses but to develop a better understanding of the experience of the teacher and the meaning she makes of that experience. Interviews were conducted in Urdu, the national language of Pakistan, because experience told us that teachers are much more comfortable talking in their native language. This research project was conceived as praxis (Lather, 1986), where the research subject is deemed to be part of the conceptualization of the research process. In that respect, Munazza helped us by noting two areas that were of concern to her in her practice as a science teacher: the order and discipline in her classes and the use of hands-on activities in teaching science. We used these concerns as a lens to observe her lessons. Nelofer attended to many things Munazza did-her routines, the teaching strategies she used, her pedagogical content knowledge-but scrutinized her use of hands-on activities and matters of order and discipline in her class with special interest.

Preparing the data for analysis involved two important processes: transcription and translation. Language is context based; some words carry a world of meaning with them and cannot be easily conveyed in another language and to another culture. Sometimes, the cultural barrier seemed so huge as to be almost insurmountable. Nelofer's reflective joumal contains the following entry: 'How much can I explain, elaborate, footnote and interpret for my readers?' The final translated materials are best referred to as 'transmuted texts'; they have been converted from one language to another and in the process have been subtly and unavoidably changed. However, they still retain the essence of the original. Analysis of data took place at several levels. The first level was the informal analysis and interpretation that takes place while interviewing and observing. The second was the reading and writing of interview summaries and field notes. This also included sharing the summaries with Munazza. Nelofer noted in her journal, 'I was keen to involve Munazza as closely as possible in constructing and reconstructing her stories and therefore I wanted to share the data with her.' Interestingly, Munazza chose to read the summaries of the interview in English. The third level was the beginning of more formal data analysis, in which the data was scrutinized to select stories for portrayal. The fourth level involved the use of an eclectic mix of techniques, such as the flip-flop technique-where the phenomena are turned 'inside out' to obtain a different perspective-and the systematic comparison of phenomena recalled either from experience or from literature to enable the comparison of concepts (Strauss \& Corbin, 1998).

In the next section, brief episodes in Munazza's life are highlighted in the form of a story. A number of rhetorical devices have been used in converting the interview data into a story. For instance, the word ' $I$ ' is used to represent Munazza's voice. By letting Munazza tell her life story in her own words, we have tried to remove the middleperson and to bring the reader closer to the teacher. To illuminate Munazza's teaching practice, we have constructed a composite story, a mosaic or collage of her memories, views, and actions, interpreted in the light of data from the life history interviews and Nelofer's classroom observations. We have tried to be true to the way Munazza communicates, by retaining almost all of the English words and phrases she used during the interview/conversations.

\section{Munazza's story}

We are eight sisters and one brother who belong to the Mohajir community. My grandparents migrated to Pakistan from Allahabad, India, in 1947. We actually had two brothers, but I lost my brother Aftab at a very young age. He had just completed Interscience ${ }^{5}$ and was ready to go to an engineering university. He and I were sitting together completing the forms needed for application to the university. I left the room for a few minutes to go to the bathroom. On my return I saw him lying face downwards. That was the last that I saw him alive. This traumatic event has left a lasting impression on all of us siblings. I have been particularly affected as I was the one with him during 
his last moments and I used to share a room with him. He was very intelligent and would have made a very competent engineer.

Now when I look at the students in my class, particularly boys, I want to make sure that they study and do well in their exams. I see my role as teacher not only to complete the curriculum but to teach in such a way that students get good marks. That will enable them to get admission to professional institutions and they will be able to make something of their lives. My own example is there. I had good marks in Interscience, sufficiently high to merit admission to a medical college in the interior of Sindh. However, I could not get admission to the medical college of my choice in Karachi, hence I could not do medicine-a profession that I was very interested to follow. I know how important marks are, and I try hard to teach the students in such a way that they will get good marks. In fact, the happiest moment in my life is when I see the board (referring to Karachi Board) results and my student have got good marks.

\section{My school life}

School life was the best part of my life. I liked the primary school years more than the time spent in the secondary school, and I liked secondary school more than the college years. School, particularly primary school, was like home to me, with our own class teacher and a room of our own to sit and study. My favourite teacher in the primary school was Miss Iffat.

When I came to the secondary school, I found that the same feeling of home was missing from the school, although the school building was the same-it seemed very different and I did not enjoy it, as the environment seemed to change. Every so often teachers would warn us in a stern voice, 'This is the secondary and not the primary school'; or 'Don't do this; don't do that.' This is particularly true for Class 6 . I found the transition from primary school to secondary school very difficult.

Our science teachers were not very good. In the primary science classes, it really did not make too great a difference, as we had to learn short answers to questions given at the end of the chapters. Science teaching in the middle grades was so-so; if it was not good, it was not bad either. The teachers made us do just enough science so that we could answer the questions given at the end of the chapter. There was no serious attempt to explain and help us to understand. However, in secondary science classes I found my science teachers to be very poor teachers. They did not have any concept of giving explanations. In particular, our physics teacher did not explain properly. She asked us to read aloud from the textbook and that was all; her work was finished. If we asked her to explain further, she would explain a bit or scold us. She would say, 'It is so easy and you do not understand.' It was obvious that we did not understand and that is why we asked her for explanations. I think at the very least, students should understand what they are reading. To just read the science textbook, which was beyond our understanding, and to let it go at that was not good teaching practice. We did not follow (understand) anything. Though our school is English-medium and we are expected to teach in English, I use Urdu a great deal in my class, at least for the oral explanations. I think that what is the use of teaching if the students do not understand what you are saying. And I, too, make the students read from their English textbooks but then I go on to give detailed explanations, with the help of activities, charts, and other aids. I ask the students to read because that helps them to get familiar with the text and read it more easily at home.

No activities were conducted in the science classes to illustrate concepts. Doing activities was unthinkable. The teachers were even unwilling to explain orally in class. Practicals ${ }^{6}$ in science were conducted in the same way that they are held here in KMSS. The class was divided in groups of 3 to 4 students. Miss ${ }^{7}$ gave the explanation about the practical to the whole class and then the students went ahead with the practical work. Our chemistry and biology teacher did try to explain and answer our questions. That is why I like biology and I wanted to make medicine my career. 
I do not know where I got my interest in science. My science teachers did not inspire me. None of my three elder sisters studied science; I was the first person in the family to take it up. I was very interested in science activities from a young age. Any activity that I read in the textbook-for instance, about the bending of a pencil when dipped in a glass of water-I would do at home to see what would happen. Why did it bend? I would do most of these activities with my sisters, Maryam and Nadia. Usually our textbooks had pictures illustrating the activity and a few lines explaining how to do it. We followed the instructions closely and tried to see what happened. The 'reason' for why such and such happened was usually given in the textbook, but very often we did not understand these explanations. It was much later, when I went to first-year and second-year of college, that I realized that what we had observed (referring to the bending of the pencil) was refraction. This was true for a lot of science that we did in school. I only understood the concept much later.

\section{My life as a teacher}

I think I try consciously to teach the way my science teachers did NOT teach. Let me explain. When I was studying in school, my science Miss did not show or explain anything with the help of activities. She just used the textbook to read and give oral explanations-if that. As a result, often I did not understand what I was memorizing. When I came home, I did some of the activities suggested in our textbook and observed carefully; then I understood much better. Often, I thought, 'I wish our teachers would teach us in this way. I wish they would explain more. I wish they would show us things.' I can say from personal experience that seeing and doing helped me to understand. That is why I try to show things to my students. That is why I say that sometimes I teach the way I was not taught.

I would describe the method that I use to teach science as the 'normal' way. I do not use any special way to teach. My biggest concern is that whatever I know I should be able to transfer to my students. If I know a lot but I cannot transfer it to the students, then that means that I am not teaching correctly. There are many teachers in KMSS who have a lot of knowledge, but they teach in such a way that the children do not understand.

I teach General Science 8 to Classes 7 and 8, chemistry to Grade 9 and Islamiat ('Islam as a religion') to another Grade 8. In Class 9, the stress is on completing the syllabus and ensuring that the students learn the answers to the important questions so that they can regurgitate it for their board exams. ${ }^{9}$ However, in Classes 7 and 8 , where exams are school based, I feel freer to teach with the help of activities. For instance, in Class 7, I demonstrated filtration to show how water is purified for drinking purposes. When the students see clean water coming out of the filter paper they understand the concept of filtration better than if $I$ had just told them about it.

\section{A glimpse of my teaching practice}

I want to share one episode of my teaching, from the first of four lessons I taught concerning the excretory system of mammals. In the first lesson, I focused on the kidneys. I used two different kinds of teaching aids for this lesson-a chart of the excretory system of mammals and a sheep's kidney that I had asked my mother to buy when she went to the market for meat. I had kept it in the freezer to be used by all three science teachers of Class 8 when we taught the excretory system. I always spend my own money to buy such simple aids for teaching science, and I have never asked for any reimbursement from the school.

I first introduced the topic of excretion, listing the organs of excretion on the blackboard. Then I explained each briefly, focusing greater attention on the kidneys with the help of the chart. I described the physical features of the kidney and told them that it is shaped like a bean. I pointed out that the membrane covering the kidney is called the peritoneum. I then held up the kidney high to show to the class that the inner structure of the kidney is of a different colour than the outside 
and is called the cortex. However, it was difficult for the students to see that, because the frozen kidney had changed colour and there was little difference between the outer part of the kidney and the cortex. Besides, the kidneys were too small for the students to see from so far away. Many of the boys and girls shouted, Miss dikhain, Miss dikhain ('Miss show us; Miss show us'). They were keenly interested.

I was gratified by their curiosity. I took the two sections of the kidney and started circulating in the class, showing the section of the kidney to groups of four students. I tried to show the cortex and the fine vessels inside the kidneys to the class. I also realized that at this rate all of the students would not be able to see the kidney. So I gave one row of students a section of the kidney to see and pass on to others. What frustrated me was that I soon had to take that kidney section back from the students because they started to play with it.

There were some students, mostly girls, who refused to handle the now wet and slimy sample of the kidney because they 'could not bear to touch it.' They asked the boys to show them the specimen from afar. The noise level in the class rose to an unacceptably high level and I admonished the students who refused to touch or see it. I truly could not see what there was to be squeamish about! Some students wanted to go and wash their hands, some held up their nose against the smell. I scolded them and told them that I did not find the specimens smelly or dirty. Finally, I threatened to - call Mrs. Jamshed, their class teacher, to restore order. Tomorrow, I must ensure that all the students write the answers of the selected questions in their registers (notebooks).

The next day when I went to the classroom for my science lesson with the same class (Class 8) I had to wait outside for more than five minutes. I could hear Mrs. Jamshed loudly reprimanding the students for their bad behaviour. I could see that she had punished some students. I saw Mrs. Halai walking up the stairs to the classroom. She and I walked almost together into the class. She settled down in a seat at the back; it took me a little longer to settle down. Three boys were sitting on the floor. This was their punishment for being late to class. Other students informed me that they were to be punished in this way for the rest of the school day. I ignored that piece of information. I believe the punishment should last as long as the period in which it was given. And anyways I don't like students to sit on the floor in my class. I asked the boys to get up from the floor and take their seats. Their seats had been taken up by other boys and had to be vacated under protests that their punishment was not yet over. It took me a while to restore order to the class and start my lesson.

In another instance, in Class 7 , the teacher who was teaching before me had made a boy make a ponytail because he had long hair. When I reached the class, the boy had removed the ponytail, but tufts of hair were angrily standing out where the ponytail had been. He asked permission to go to the bathroom to comb his hair. As a rule, I do not let students go out during my class but I made an exception this time, because I felt he needed to put his hair right. Adolescent boys are very sensitive about their appearance, particularly in front of girls, and hence I did not want him to suffer more than he had.

I think part of the reason that I have so much difficulty in class management is that I do not use strict punishments for my students. They are not afraid of me. I wish they were; then they would at least keep quiet in my class.

\section{Munazza's conception of the nature of science}

Lengthy conversations with Munazza and observation of numerous lessons over a period of 17 months indicate that her conception of the nature of science has five significant elements, each of which is rooted in her personal history:

- Observation is independent of theory.

- Science is received knowledge. 
- Science is a superior, value-free, and stable way of knowing.

- Science education is principally a matter of enculturation into the language of science.

- Science is a masculine subject.

\section{Scientific observation is independent of theory}

When learning science in school, Munazza wanted to 'see things for herself.' She was very disappointed that her teachers never demonstrated the various activities listed in her textbook. Together with her siblings, she performed these activities at home and (according to her) got a much better understanding of some of the science concepts than she had gained from class. As a teacher, Munazza continues to believe that 'seeing' or 'doing' helps students to understand better. She wants to expose her students to more than just reading the textbooks and notes. Hence, she goes out of her way to provide opportunities for students to see science phenomena. She has developed a repertoire of activities that work for her, and she continually adds new activities to this list, in a way similar to that described by Louden (1991) in his case study of Johanna. This is a major advance from the rote methods of teaching usually observed in Karachi science classrooms. Some standard practical work could be anticipated in Classes 9 and 10 (Hill \& Tanveer, 1990), but it is uncommon in Classes 7 and 8. In that respect, Munazza could be described as an innovative teacher.

Activities in the science classroom achieve a number of things for Munazza and the students, in addition to helping her to teach the content. Practical demonstrations during a science class provide children with a memorable image of what 'science is' and 'what scientists do,' and serve as a powerful motivator for the students. The fancy equipment with strange names and the 'dangerous' chemicals add a bit of excitement to a generally not very stimulating school day and serve to reaffirm the expectations of science lessons held by other teachers and school administrators.

Munazza believes that her students 'see' the same as she does when looking at a science demonstration: All students have to do, she believes, is to see the activities and they will inevitably and unerringly abstract the principle or concept she wishes to illustrate. In other words, observations give reliable information about the world. Roth $(1995$, p. 3) writes about the strikingly similar views he held when he started to teach science: 'I began to teach science assuming that all students had to do was to look and recognize the truth about nature; I assumed that what I saw happening in a test tube should be seen equally by students.' Roth soon changed his views; unfortunately, Munazza has yet to change hers-though her experiences in this research project show some promising signs of eventual change. Munazza has not yet fully realized that students 'see' very differently from the teacher. Teachers utilize their theoretical framework in designing and implementing practical activities but, not having that particular theoretical lens, students often see things very differently. For example, studies in which students are expected to draw the internal structure of a plant cell after observing it under a microscope show clearly that students often focus on something entirely different. Even with guided activities, students do not always see 'eye-to-eye' with the teacher. For example, in a science class where the teacher (not Munazza) was using balloons to show that air has weight, the students regarded the colour of the balloons as an important variable in the experiment. Hodson (1998a) comments on this problem as follows:

The traditional school curriculum description of science says two things about observation. First, nothing enters the mind of the scientist except by way of the senses-that is, the mind is a tabula rasa on which the senses inscribe a true and faithful record of the world. Second, the validity and reliability of the observation statements are independent of the opinions and expectations of the observer and can be readily confirmed by other observers. Neither is true. In reality, we interpret the sense data that enter our consciousness in terms of our prior knowledge, beliefs, expectations, and experience. (p. 10) 
Gunstone's (1991) reminder that 'looking at' is an active process in which students check their perceptions against their expectations is lost on Munazza. She seems blithely unaware that her students do not always see what she sees and is clearly frustrated when her students remind her. For example, she regarded her demonstration with the sheep's kidney as a clear illustration of how mammalian kidneys function, while her students, especially the girls, saw the kidney as a slimy, semi-alive animal organ that they refused to touch. When she demonstrated filtration to the class, she intended it as a model of how water is made safe for drinking. Her students saw it as water passing through paper and could not see the connection between the water they drink and the filtrate-particularly when she did not allow a boy to drink the filtrate when he offered to do so. Munazza conducts practical activities in the class to motivate, illustrate, clarify, and enhance understanding. However, because of her naïve belief in theory-free observations, they also have the capacity to confuse.

Munazza succeeds in fulfilling one of the functions of hands-on activities in the science classroom: the acquisition of descriptive knowledge. However, she fails to direct attention to the abstract theoretical ideas needed to make sense of the observations. The failure of so much of her practical work is a consequence of focusing on the activity rather than the meaning making. Driver (1983) could be talking about Munazza when she says: 'It is common to see science lessons which end with the clearing up after the practical work is finished. The time for the important discussion of how the experiences gained relate to the new ideas is missed. Activity by itself is not enough. It is the sense that is made of it that matters' (p. 49). Gunstone (1991) makes a similar point: '[F]or practical work to have any serious effect on student theory reconstruction and linking of concepts in different ways, the students need to spend more time in interacting with ideas and less time interacting with apparatus' (p. 74).

\section{Science is received knowledge}

For the topic of vertebrates and invertebrates with Class 7, Munazza had planned the lessons thoroughly and had gone to great trouble to procure preserved samples of the first four of the categories of vertebrates. First, she described the five major classifications of vertebrates: mammals, birds, reptiles, amphibians, and fish. Next, she explained the dominant characteristics of a dogfish, a flounder, and a frog, using specimens preserved in formalin. Where specimens were not available, as in the case of bird and reptile, she used pictures from the textbook. To explain about human beings as vertebrates, she produced four bones from the spinal column of a human skeleton. Although the students found the lesson very interesting, they were left with the impression that nature intended animals to be classified in such a way. Although Munazza is fully aware of the Swedish biologist Linnaeus and his remarkable achievement in devising the classification of animals, her lesson suggested that the classification system was received from a divine authority, as a fait accompli. Because she failed to point out the human effort and creativity that went into the classification process, an important aspect of the nature of science was missed.

Munazza's lesson on vertebrates serves to illustrate the nexus of knowledge and authority in Pakistan. The notions that knowledge is truth and 'truth is for all time' are common aspects of thinking about science knowledge in many parts of the world (Krugly-Smolska, 1995), and in Pakistani society, as in that of many other countries of the world, powerful knowledge like science is closely associated with authority (Fuller \& Snyder, 1991; Shumba, 1999). The idea of challenging authority is very difficult for Pakistani students, so much of the knowledge in books is accepted without question. Questions in science such as 'Why are animals classified in this manner?' are never raised. Classification is accepted as a fact, as a given, or even as a revealed truth. Like most other science teachers in Pakistan, Munazza teaches science in a way that adds to the 'mystique' (Lemke, 1990), the 'mythology' (Smolicz \& Nunan, 1975; Nadeau \& Désautels, 1984), or the persistent falsehoods and 'fiction' (Hodson, 1998b) of science. She does not make clear that science is 
a human endeavour and, therefore, subject to human frailties. Of course, this approach is not unique to developing countries like Pakistan; it is also depressingly common in developed countries. As Lemke (1990, p. 175) remarks, 'It is dangerous to society to have students leave school believing that science is a perfect means to absolute objective truths, discovered by people of superhuman intelligence.'

\section{Science is a superior, value-free, and stable way of knowing}

When asked what she understood by 'science,' Munazza responded, '[A] body of knowledge based on empirical evidence.' She was able to illustrate her conception of science with examples and stories. It is the ability to yield empirical evidence that makes science distinctive: 'One can perform an experiment and prove a claim in science, whereas one cannot do that in other forms of knowing such as religion.' She attaches a great deal of importance to experiments as a means of 'discovering the laws of science and developing scientific theory.' Munazza sees a separation between the form and the content of science. She values the progress in industry and technology that science has brought to the world, yet rejects the materialism and individualism that goes with it. She separates science as 'worldly knowledge,' which she regards as neutral and value-free, from religious knowledge, which falls within the realm of faith. Because of her experience teaching Islamiat, Munazza often uses religion as a counter-text to compare with science.

Munazza values science because it helps to explain many things that were not known before. This includes many stories and metaphors used in the Holy Qur'an. For example, she used the example of Mairaj ('Zenith') when the Prophet Mohammed (Peace Be upon Him) ascended the seven heavens to communicate with God. This joumey and conversation of considerable length was accomplished in the blink of an eye. Tradition illustrates the time it took for the Prophet to accomplish this journey by explaining that when he left, the chain used to latch the door started to swing. When he retumed, it was still swinging. Munazza said that, when she first heard the story, it seemed 'improbable' to her, but now she can understand it on the basis of Einstein's theory of relativity. It appears that Munazza agrees with Malinowski's (1948) division of phenomena into the accountable and the unaccountable. She values science because it enlarges the domain of knowledge that appears to be accountable. She continues to use her faith in Islam to accept many unaccountable facts or events that have been mentioned in the Qur'an, like the presence of Jinns, ${ }^{10}$ but as yet have not been explained by science. She is sure that science will eventually be able to explain everything. She is unsure about the distinction between absolute truth and scientific truth and believes science to be true and 'there for all times.' In this context, her view is at variance with that of most contemporary philosophers of science, who believe science to be tentative and revisionary in nature.

\section{Science is enculturation into the language of science}

Munazza thinks of science as 'a special way of putting things.' She believes that science has a unique language and that knowing how to use the language is even more important than understanding it-at least for students at this stage in their school life. She wants her students to speak like scientists rather than use everyday words. At every stage of her science program and at every step in the lesson, an attempt is made to initiate the students into the language of the subject. Words like filtrate and residue are used, even in circumstances where simpler words are available. Just as one learns one's native language by speaking it, Munazza argues, one learns the language of science by using it as much as possible and at as young an age as possible. A language teaches a lot more than terminology-it enculturates-it teaches the embedded rules of the culture and provides a tool for social interaction. In his influential study of classroom science teaching, Lemke (1990) concludes that mastery of science is basically a matter of learning how to talk science. Science talk 
in the classroom helps students with abstract generalizations and logical relationships. Hence, a major part of enculturating students into science is achieved through language. In this respect Munazza's science teaching shows evidence of exemplary practice.

Although she works in an English-medium school, Munazza does most of her teaching in Urdu. She explains that it is absurd to continue to teach in English if her students do not understand her. Munazza sees it as her responsibility to expose the students to the language of science as much as possible, but she does not think that it is her responsibility to teach English to the students. So, while she understands that Urdu will help her students to understand what she is saying, words such as filtrate and residue are used because they initiate students in the vocabulary of science. There is ample evidence (Watson \& Bashe, 1996) that using mixed languages (English and mother tongue) is a fairly common practice in many parts of the developing and the developed world. A study conducted in Kenya by Cleghorn (1992) found that ideas were conveyed more effectively to students when teachers did not adhere to an English-only policy. Thus, Munazza's use of both English and Urdu to convey her meaning may be considered a well-founded practice that has contributed to her students' understanding science better.

\section{Science is a masculine subject}

Locating the research in a co-educational school provided rich opportunities for studying the influence of student gender in the science classroom. The school has a 2:3 ratio of girls to boys. The girls' conduct can be largely characterized in terms of quietness, obedience, good behaviour, and good grades. Nevertheless, the boys' contributions seemed to be valued more highly. Interviews with four other science teachers in the school showed that they (as well as Munazza) tended to dismiss girls as 'book learners,' even when they obtained better grades than boys (Halai, 2002b). All of the teachers said that they appreciated the boys for their 'better understanding of science.' The female science teachers, in particular, mentioned that the boys were particularly adept at practical work related to electric circuits and electrolysis.

Boys were much more actively involved during science activities; they dominated the class dialogue. However, Munazza realizes that and ensures that girls also take an active part in the class in a number of ways. When Munazza takes the students to the laboratory to do practical work, she makes sure that girls are in all-girls groups so that they get a chance to work with the science materials and are not relegated to service roles, where they are expected to collect equipment, collect data, or clean up afterwards (Kelly, 1985). She encourages girls to go to the blackboard or to respond in class by giving them lots of wait time. She encourages all students, and particularly girls, by saying 'If you respond, at the worst, what will happen? You might be wrong. This is the only way you can learn.' She does not believe that 'equality' is needed in dealing with boys and girls in the class, preferring treatment that is more 'gender appropriate' within the Pakistani cultural context. She accepted all kinds of responses from the girls when they volunteered in class. For instance, in a lesson on water with Class 7, where the girls were much 'quieter' than the boys, she accepted an explanation of the water cycle from a girl in the first row. The student spoke so softly that it is likely that even the girl sitting next to her could not hear her, but Munazza accepted the answer without fuss, in a clear effort to encourage the girls to take a more active part in the class.

In the highly patriarchal society of Pakistan, discussion about the teaching and learning of science has to take into account the masculine image of science. The manner in which science is packaged and presented in the class-in particular, the examples and applications that are stressedgive the impression that only males do science. Munazza is very proud of her record of always teaching science to boys (or classes where boys are in the majority), because teaching them is 'more difficult' and has higher status. The high status is partly due to the fact that the principal goal of science teaching-gaining admission to science careers in medicine and engineering-is considered more important for boys than for girls. Munazza thinks that it is 'more difficult' to teach boys 
than girls because boys ask lots of questions. She says that this may make teaching difficult but it is advantageous for other students and even for the teacher. The questions raised in the class help the girls (and other boys) to understand the content better and often serve to enhance the teacher's own understanding of the science topic. She says that this was precisely her experience when she was studying in college-she learned more when she was in a class full of boys. The boys invariably asked good questions that helped her understanding of science. Munazza said, 'Boys know more than girls do, perhaps because they are allowed to "go out." They ask better questions, so the girls, too, learn by this interaction between the teacher and the boys.'

The masculine image of science is exemplified in Munazza's class in a number of ways. The larger number of boys in the classes naturally tips the balance in favour of boys; classroom behaviour and personal interactions are affected by the concepts of femininity and masculinity developed in the wider society outside the classroom. As Brickhouse (2000) reminds us, societal ideas of what girls and boys can and cannot do (or should and should not do) will inevitably govern the practice of science teaching. In that sense, these influences are not specific to Munazza's science class in the school. They are common to most science classrooms in Karachi's schools.

\section{What can we conclude?}

This study raises a number of questions. If teachers' practice is so rooted in their biography, how can we utilize this finding to help them change their practice? How can teachers' conceptions of the nature of science be changed on those occasions when we, as teacher educators, believe it to be unsatisfactory? Conclusions such as 'Teachers teach who they are' are no more than abstract aphorisms until they are converted into pedagogical practices that work in the classroom.

Clearly, early experiences influence beliefs and behaviours regarding teaching and learning. Enabling teachers to identify these life experiences provides them with insight into their philosophical position about education, about the nature of science, and about the influences that affect pedagogical decisions taken in their classrooms. Often, it is not the facts and events of the life story that are important but the interpretation given to them that is meaningful for the teachers. Opportunity for teacher educators to engage in this kind of reflection with teachers has some distinct benefits. It has the potential of making explicit the difference between a teacher's 'espoused theory' and 'theory-in-use' (Argyris \& Schon, 1980). Through confronting this, teachers can become more aware of their theory-in-use. They can be assisted to reflect on it, modify and develop it, and in consequence, learn to act more effectively in and outside the classroom. For example, Munazza has recognized that practical work has great benefits for students in allowing hands-on experience of many natural phenomena, but working with Nelofer, and reflecting on her personal practical knowledge, has helped her to realize some of the limitations that need to be considered: first, her view that observations are independent of theory and that hence all students observing a phenomenon will see the same thing as the teacher; and second, her belief that practical work 'speaks for itself and that, hence, no post-practical-work discussion of outcomes is needed. Even a slight modification of Munazza's practical demonstrations, incorporating Gunstone's (1991) predictobserve-explain (POE) method to take account of students' prior knowledge, for example, would increase their effectiveness quite substantially.

The significance of this research is located in what it tells us about professional development practices in Pakistan. It shows how closely personal experience as a student is related to teaching practice and highlights how a teacher's individual life events can affect her teaching. It shows that helping teachers to uncover and understand these critical incidents can assist them in understanding, critiquing, and re-conceptualizing their teaching. Science teaching can also be improved by developing activities to help teachers reconstruct their own concepts of the nature of science and then using these same activities to teach students about the nature of science (Halai, 1999). In Paki- 
stan, the greatest challenge lies not in developing curricula and new ideas but in supporting teachers in implementing them and refining them to suit their particular needs and the needs of their students. This study has shown very clearly that teachers use their personal practical knowledge to make decisions about what and how to teach in class and that the basis for this kind of knowledge is their life history. It follows that attempts at significant curriculum development, and the associated professional development of teachers, should strive to make curriculum innovation a prominent part of the experience of all teachers.

\section{Notes}

1 Pseudonyms have been used for all teachers and family members mentioned in this article, and for the school.

2 Afternoon-shift schools in Karachi normally remain open for 4.5 hours, rather thar the more common 5 hours. School starts at 12:30 or 1:00 p.m. and ends at 5:00 or 5: 30 p.m. Hence, it is common for these schools to remain open one Saturday a month to make up for the lost time.

3 A full definition is available at http://www.nsta.org/159\&psid=22.

4 All interview data was bilingual, as Munazza used both Urdu and English to express herself. The interviews were translated into English by one of the authors (Nelofer Halai).

5 The first two years of college, equivalent to Grades 11 and 12, are called intermediate classes. Science studied in intermediate classes is referred to as Interscience.

6 Refers to the laboratory experiments prescribed in the syllabus.

7 In many schools in Pakistan, a female teacher is called 'Miss,' regardless of her marital status.

8 General Science refers to a science course where physics, chemistry, and biology are integrated.

9 A three-hour public exam conducted by the Karachi Board of Secondary Studies.

10 Supernatural beings.

\section{References}

Abd-El-Khalick, F., Bell, R.L., \& Lederman, N.G. (1998). The nature of science and instructional practice: Making the unnatural natural. Science Education, 82(4), 417-436.

Argyris, C., \& Schon, D.A. (1980). Theory in practice: Increasing professional effectiveness. San Francisco, CA: Jossey-Bass.

Brickhouse, N. (2000). What kind of a girl does science? The construction of school science identities. Journal of Research in Science Teaching, 37(5), 441-458.

Clandinin, D.J. (1985). Personal practical knowledge: A study of teachers' classroom images. Curriculum Inquiry, 15, 362-385.

Clandinin, D.J. (1986). Classroom practice: Teacher images in action. Philadelphia, PA: Falmer Press.

Cleghorn, A. (1992). Primary level science in Kenya: Constructing meaning through English and indigenous languages. International Journal of Qualitative Studies in Education, 5(4), 311323.

Cole, A.L., \& Knowles, J.G. (1993). Teacher development partnership research: A focus on methods and issues. American Educational Research Journal, 30(3), 473-495.

Connelly, F.M., \& Clandinin, D.J. (1985). Personal practical knowledge and the modes of knowing: Relevance for teaching and learning. NSSE Yearbook, 84, 174-198.

Connelly, F.M. \& Clandinin, D.J. (1988). Teachers as curriculum planners. New York: Croom Helm.

Denzin, N.K. (1989). Interpretive biography. London: Sage.

Driver, R. (1983). The pupil as scientist? Milton Keynes, UK: Open University Press. 
Fuller, B., \& Snyder, C.W. (1991). Vocal teachers, silent pupils? Life in a Botswana classroom. Comparative Education Review, 35, 274-293.

Goodson, I.F. (1992). Studying teacher's lives: An emergent field. In I.F. Goodson (Ed.), Studying teacher's lives (pp. 1-17). New York: Teachers College Press.

Gunstone, R.F. (1991). Reconstructing theory from practical experience. In B. Woolnough (Ed.), Practical science: The role and reality of practical work in school science (pp. 67-77). Milton Keynes, UK: Open University Press.

Halai, N. (1999, April). Elementary teachers learn about the nature of science: New frames for experience. Paper presented at the annual meeting of the American Educational Research Association, Montreal, April 19-23.

Halai, N. (2002a). Nature of science research protocol (NOSRP): Revised version. (Unpublished interview protocol being used in the study Understanding and Enhancing Science Teachers' Conceptions of the Nature of Science: A Study in Curriculum and Professional Development. Available from the author).

Halai, N. (2002b). Munazza's story: Understanding science teaching and conceptions of the nature of science in Pakistan through a life history study. Unpublished doctoral dissertation, University of Toronto.

Hill, J.C., \& Tanveer, S.A. (1990). Developing a program to improve science education in Pakistan: A six year implementation cycle. Science Education, 74(2), 241-251.

Hodson, D. (1991). Philosophy of science and science education. In M.R. Matthews (Ed.), History, philosophy, and science teaching: Selected readings (pp. 19-32). New York: Teachers College Press.

Hodson, D. (1998a). Teaching and learning science: Towards a personalized approach. Philadelphia: Open University Press.

Hodson, D. (1998b) Science fiction: The continuing misrepresentation of science in the school curriculum. Curriculum Studies, 6(2), 191-216.

Kelly, A. (1985). The construction of masculine science. British Journal of Sociology of Education, 6(2), 133-154.

Krugly-Smolska, E. (1995). Cultural influences in science education. International Journal of Science Education, $17(1), 45-58$.

Lather, P. (1986). Research as praxis. Harvard Educational Review, 56(3), 257-277.

Lederman, N.G., Wade, P.D., \& Bell, R.L. (1998). Assessing the nature of science: What is the nature of our assessments? Science \& Education, 7(6), 595-615.

Lemke, J.L. (1990). Talking science: Language, learning, and values. Norwood, NJ: Ablex.

Louden, W.R. (1991). Understanding teaching: Continuity and change in teachers' knowledge. New York: Teachers College Press.

Malinowski, B. (1948). Magic, science and religion. Boston, MA: Beacon.

McComas, W.F., Clough, M.P., \& Almazroa, H. (2000). The role and character of the nature of science in science education. In W.F. McComas (Ed.), The nature of science in science education: Rationales and strategies (pp. 3-39). Dordrecht: Kluwer.

Nadeau, R., \& Désautels, J. (1984). Epistemology and the teaching of science. Ottawa: Science Council of Canada.

National Science Teachers Association. (2000). NSTA position statements: The nature of science. Available: http://www.nsta.org/159\&id=22 (accessed October 4, 2004).

Nott, M., \& Wellington, J. (1998). Eliciting, interpreting and developing teachers' understandings of the nature of science. Science \& Education, 7, 579-594.

Roth, W-M. (1995). Authentic school science: Knowing and learning in open-inquiry science laboratories. Dordrecht: Kluwer. 
Shulman, L.S. (1986). Those who understand: Knowledge growth in teaching. Educational Researcher, 15, 4-14.

Shulman, L.S. (1987). Knowledge and teaching: Foundations of the new reform. Harvard Educational Review, 57(1), 1-21.

Shumba, O. (1999). Relationship between secondary science teachers' orientation to traditional culture and beliefs concerning science instructional ideology. Journal of Research in Science Teaching, 36(3), 333-355.

Smith, L.M., Kleine, P.F., Prunty, J.P., \& Dwyer, D.C. (1986). Educational innovators: Then and now. New York: Falmer Press.

Smolicz, J.J., \& Nunan, E.E. (1975). The philosophical and sociological foundations of science education: The demythologizing of school science. Studies in Science Education, 2, 101-143.

Stake, R.E., \& Trumbull, D.J. (1982). Naturalistic generalizations. Research Journal of Philosophy and Social Science, 7, 1-12.

Strauss, A., \& Corbin, J. (1998). Basics of qualitative research: Techniques and procedures for developing grounded theory. Thousand Oaks, CA: Sage.

Watson, P., \& Bashe, L. (1996). Voice from the classroom. Johannesburg, South Africa: Sethlare Trust. 